\title{
EKSISTENSI PERBANKAN SYARIAH MELALUI DOMINASI PEMBIAYAAN PROFIT AND LOSS SHARING
}

\author{
Trimulato Trimulato \\ Universitas Islam Negeri Alauddin Makassar, Indonesia \\ tri.mulato@uin-alauddin.ac.id \\ https://doi.org/10.46367/jps.v2i1.287
}

Received: Feb 22, 2021 Revised: Mar 05, 2021 Accepted: Mar 24, 2021 Published: Apr 09, 2021

\begin{abstract}
The beginning of the presence of the first Islamic bank in Indonesia was known as a bank with a profit and loss sharing concept. But in reality, profit and loss sharing financing is no longer dominant in Islamic banks, because non-profit sharing financing is more dominant, especially financing with the buying and selling model. The purpose of this research is to determine the development of financing in Islamic banks, as well as to determine the need to dominate profitsharing financing in Islamic banks. This research is a qualitative descriptive which shows the development of Islamic bank financing products and the need to restore the concept of profit and loss sharing to be dominant in Islamic banks. The results of this study indicate that the growth of period financing is quite good. Then there are three reasons for the need to dominate profit and loss sharing financing in Islamic banks, namely restoring the identity of the Islamic bank as a profit-sharing bank, being the main differentiator between conventional and Islamic banks, and the opportunity to grow the real sector with greater income.
\end{abstract}

Keywords: Financing Products, Profit and Loss Sharing, Shariah Banking.

\begin{abstract}
ABSTRAK
Awal kehadiran bank syariah pertama di Indonesia dikenal sebagai bank dengan konsep bagi hasil. Tetapi kenyataannya pembiayaan bagi hasil tidak lagi menjadi dominan pada bank syariah, sebab pembiayaan non bagi hasil yang lebih dominan khususnya pembiayaan dengan model jual beli. Tujuan dari penelitian yaitu untuk mengetahui perkembangan pembiayaan di bank syariah, serta untuk mengetahui perlunya dominasi pembiayaan bagi hasil di bank syariah. Penelitian ini bersifat deskriptif kualitatif yang menunjukkan perkembangan produk pembiayaan bank syariah dan perlunya mengembalikan konsep bagi hasil menjadi dominan di bank syariah. Hasil penelitian ini menunjukkan bahwa pertumbuhan pembiayaan periode cukup baik. Kemudian ada tiga alasan perlunya dominasi pembiayaan bagi hasil di bank syariah yaitu mengembalikan identitas bank syariah sebagai bank bagi hasil, menjadi pembeda utama antara bank syariah dengan konvensional, dan peluang untuk menumbuhkan sektor riil dengan pendapatan yang lebih besar.
\end{abstract}

Kata Kunci: Produk Pembiayaan, Bagi Hasil, Bank Syariah. 


\section{PENDAHULUAN}

Perkembangan untuk bank syariah di Indonesia dimulai dengan berdirinya bank Muamalat yang menandai sebagai pelopor bagi bank syariah yang menerapkan sistem Islamic Bank di tengah tumbuh dan berkembangnya bankbank konvensional. Krisis moneter yang terjadi pada tahun 1998 telah menyebabkan jatuhnya bank-bank konvensional dan dilikuidasi bank konvensional yang tidak sedikit. Sementara itu, perbankan yang menerapkan sistem syariah tetap eksis, semakin diminati, semakin luas jangkauannya dan cukup mampu kuat dalam menghadapi berbagi terpaan krisis. Kejadian tersebut tidak sekedar terjadi pada tahun 1998, di tengah-tengah krisis yang pernah terjadi keuangan global yang melanda banyak negara di dunia pada penghujung 2008, lembaga keuangan syariah tetap dapat membuktikan kembali kekuatan memiliki daya tahannya dalam menghadapi terpaan badai krisis pernah terjadi. Lembaga keuangan syariah telah membuktikan ketangguhan tetap stabil tidak terpengaruh dengan kondisi yang terkadi dan tidak goyah dalam kegiatannya dan memberikan kontribusi keuntungan dan pendapatan yang maksimal, kenyamanan dan keamanan bagi seluruh pihak, fasilitas untuk keamanan terjaga dengan baik bagi para stakeholder, berupa para pemegang atau pemilk sahamnya, pemegang surat berharga sesuai syariah, para nasabah pembiayaan atau peminjam, dan para nasabah penyimpan dana pihak ketiga di bank-bank syariah dan seluruh pihak yang menggunakan produk dan bertransaksi di bank syariah. Perbankan syariah dapat membuktikan serta menjadikan setiap momentum ini untuk menunjukkan bahwa perbankan syariah kuat, memiliki nilai lebih, serta benar-benar mampu bertahan dan kebal terhadap terpaan krisis yang terjadi, serta mampu tumbuh dan berkembang secara signifikan di tengah masyarakat. Karena itu, perlu banyak upaya serta langkah-langkah kongkrit dan strategis untuk merealisasikannya dan mewujudkan perbankan syariah yang lebih unggul (Ikatan Bankir Indonesia 2014).

Keberadaan perbankan syariah di negara ini telah mendapatkan landasan hukum yang kuat setelah adanya aturan yang terus mendapat perhatian, yaitu yang berkaitan dengan lahirnya Peraturan Pemerintah Nomor 72 Tahun 1992 yang direvisi dengan hadirnya Undang-Undang tahun 1998 nomor 10 tentang perbankan, secara tegas mengakui eksistensi dan peran beserta fungsi bank syariah sebagai bank bagi hasil. Dengan demikian bank ini beroperasi dengan prinsip bagi hasil bukan bunga yang merupakan riba. Bagi hasil adalah prinsip muamalah yang dibenarkan dalam Islam yang dilakasanakan sesuai syariah dan diterapkan dalam kegiatan usaha bank. Bank syariah lahir sebagai salah satu solusi pilihan dalam kegiatan perbankan serta dapat menjadi alternatif terhadap persoalan pertentangan antara bunga bank dengan riba yang belum disatu suarakan dan adanya perbedaan pendapat. Dengan demikian, kerinduan umat muslim di Indonesia yang ingin memiliki dan bertransaksi pada sistem perbankan yang bebas dari unsur ribawi, serta masyarkat ingin melepaskan diri dari persoalan riba sesuatu yang dilarang dalam agama, kini telah mendapatkan jawaban dengan lahirnya bank syariah yang saat ini terus mengalami perkembangan yang baik. Kemunculan bank syariah di Indonesia pada sekitar tahun 1992 atau lebih tepatnya setelah hadir aturan Peraturan Pemerintah nomor 72 tahun 1992, yang kemudian direvisi menjadi Undang-Undang nomor 10 tahun 
1998 dalam bentuk sebuah bank yang beroperasinya menggunakan skema bagi hasil. Setelah itu diundangkan udang-undang nomor 21 tahun 2008 sebagai dasar hukum Operasional Bank Syariah di Indonesia. Kemajuan dan pertumbuhan yang menggembirakan bagi bank syariah, di abad ke 20 terjadinya kebangkitan umat Islam dalam segala aspek, tanpa terkecuali bidang ekonomi dan keuangan, mulai mengenal sistem ekonomi Islam. Sistem keuangan dalam perkembangannya muncullah pemikiran-pemikiran yang mengarah pada perbaikan sistem keuangan, yaitu menghapuskan instrumen bunga karena termasuk riba. Setiap usaha dilakukan dengan tujuan mencapai konsistensi dalam melaksanakan kegiatannya berjalan sesuai prinsip-prinsip ajaran Islam yang mengandung nilai-nilai keadilan, salaing percaya, tidak berlaku curang, adanya kejujuran, dan kebajikan (Muhammad 2012).

Bank syariah pertama di Indonesia didirikan pada pada tahun 1992. Bank ini berdiri berdasarkan kebutuhan masyarakat kebutuhan masyarakat Indonesia yang mayoritas penduduknya beragama Islam untuk memiliki sebuah bank yang bebas riba (bunga). Bank syariah sebagai lembaga intermediasi sebenarnya tidak dikenal pada zaman Rasulullah maupun sahabatnya. Namun, kegiatan kerjasama investasi dalam perdagangan (jual beli) dan transaksi lainnya telah dilakukan secara individual oleh para pelaku pasar yang harus mengikuti aturan-aturan syariah Islam. secara teoritis, tujuan adanya bank syariah adalah untuk memperlancar aliran investasi dari pihak yang memiliki kelebihan (surplus spending unit) disalurkan kepada pihak yang membutuhkan dana (defisit spening unit) dan pada akhirnya memperlancar berputarnya sumber daya ekonomi. Dengan demikian akan melancarkan aliran perekonomian, untuk melancarkan kegiatan sektor riil, untuk bisa menumbuhkan ekonomi. Pelayanan industri perbankan syariah kepada nasabah dilengkapi dengan berbagai instrumen keuangan yang diharapkan dapat memenuhi kebutuhan transaksi keuangan yang memenuhi prinsip-prinsip syariah. Selain dapat menguntungkan secara ekonomi, tetapi juga bisa tidak melanggar prinsip syariah, jadi bukan materi semata. Instrumen keuangan syariah yang ditawarkan tentunya harus dapat mencakup berbagai lapisan masyarakat dan industri, termasuk didalamnya kebutuhan transaksi bagi sektor konsumsi. Begitupun dengan produk yang bersifat produktif. Secara umum, produk-produk keuangan syariah dapat dibagi menjadi dua golongan utama yaitu; produk-produk keuangan syariah dasar yang digunakan dalam kegiatan perbankan secara tradisional dan produk-produk pengembangan. Produk-produk yang perlu didesain dapat memenuhi kebutuhan masyarakat, tetapi juga sejalan prinsip syariah. Produk-produk dasar keuangan syariah digunakan oleh lembaga perbankan syariah dalam melaksanakan kegiatan dasarnya sebagai lembaga intermediasi yang berfungsi untuk mentransformasikan aset likuid masyarakat kedalam berbagai investasi jangka panjang. Namun demikian, sejalan dengan perkembangan kegiatan yang terjadi, produk-produk perbankan syariah perlu untuk mengembangkan variasi produk keuangannya agar dapat secara fleksibel memfasilitasi transaksi dalam mata uang yang berbeda dan instrumenintrumen lindung nilai. Serta banyak lagi produk-produk perbankan syariah yang akan memenuhi kebutuhan masyarakat, maka inovasi sangat diperlukan (Darsono et al. 2017).

Rasio investasi terhadap PDB melampaui levelnya sebelum krisis 1997/1998. Daya tahan perbankan yang kuat menjadi peredam guncangan (shock 
absorber) bagi perekonomian. Daya redam ini ditopang oleh kekuatan modal yang memadai dalam menyerap risiko dan efektifnya pengaturan dan pengawasan perbankan. Ketahanan dan sistem pengawasan perbankan yang efektif telah mendorong perbankan menjalankan fungsi intermediasi penyaluran pembiayaan secara maksimal dan disertai dengan tingkat kredit bermasalah yang masih terkendali. Arah kebijakan perbankan syariah akan mengacu kepada 3 (tiga) koridor yang saling terkait yaitu: (i) pemeliharaan stabilitas sistem keuangan, (ii) penguatan ketahanan dan daya saing perbankan, dan (iii) penguatan fungsi intermediasi, termasuk program keuangan inklusif, yang dapat lebih bermanfaat bagi perekonomian serta masyarakat yang lebih luas (Bank Indonesia 2013).

Pada suatu kesempatan dalam forum diskusi bapak Kartiko selaku direktur utama bank mandiri, bank mandiri pemilik anak usaha bank syariah mandiri menyampaikan bahwa pada posisi funding atau penghimpunan dana di bank syariah cukup baik hanya saja kesulitan untuk menyalurkan dana yang terkumpul tersebut, dari sisi financing atau pembiayaannya masih sulit. Beliau menambahkan bahwa masyarakat belum begitu merasakan adanya perbedaan antara bank syariah dengan bank konvensional. Kemudian beliau menyampaikan bahwa perlu adanya formula terhadap produk bank syariah yang sekiranya nampak perbedaan dapat dirasakan pengguna bank syariah (Metrotvnews 2016).

Konsep bagi hasil (profit and loss sharing) yang menjadi jiwa atau penggerak bagi bank syariah sebenarnya menjadi pembeda utama antara bank syariah dengan bank konvensional (Trimulato 2017). Jika di bank konvensional segala sesuatunya bersifat pasti dari segi pendapatan yang akan diperoleh oleh pihak bank atau pihak nasabah, maka konsep bagi hasil tidak bisa memberikan kepastian pendapatan. Pendapatan yang akan diperoleh akan berfluktuasi mengikuti kinerja atau produktifitas dari usaha atau kegiatan ekonomi yang dijalankan. Core model dari konsep bagi hasil yang akan menampakkan perbedaan yang sangat terasa antara pengguna bank syariah dengan pengguna bank konvensional. Hanya saja karena saat ini bank syariah banyak menggunakan pembiayaan yang non bagi hasil khususnya pada produk pembiayaan sehingga nampak konsep antara bank syariah mirip dengan bank konvensional yang selalu menuntut adanya kepastian pendapatan dan pengembalian. Serupa dengan konsep bank konvensional yang segala sesuatunya bersifat tetap (fix income).

Jenis pembiayaan di bank syariah didominan oleh pembiayaan murabahah, yaitu jenis pembiayaan dengan skema jual beli kemudian jenis pembiayaan dengan produk pembiayaan kerjasama menggunakan akad musyarakah menggunakan bagi hasil. Produk musyarakah di BPRS periode Agustus tahun 2016 mengalami pertumbuhan sebesar 19\% mengalami peningkatan tahun sebelumnya hanya sebesar $14,9 \%$. Sedangkan pembiayaan jual beli murabahah di BPRS pada periode Agustus tahun 2016 tumbuh 9,6\% yang melambat dari tahun sebelumnya yakni sebesar 13,3\%. Pertumbuhan pembiayaan musyarakah meningkat pada periode Agustus 2016 hal ini menunjukkan terjadinya transisi praktek bagi hasil yang cukup baik. Pelaksanaan produk bagi hasil di bank syariah terjadi transisi dari sebelumnya bentuk revenue sharing beralih ke bentuk profit and loss sharing kemudian perlahan dan perlu ditingkatkan (Agza and Darwanto 2017). 
Pembiayaan dengan model bagi hasil minim digunakan oleh bank syariah bahkan melebihi 60 persen pembiayaan tidak menggunakan konsep bagi hasil. Sebagaimana data yang dikelurkan oleh otoritas jasa keuangan sebagai berikut:

\begin{tabular}{ccc}
$\begin{array}{c}\text { Tabel 1. Porsi Penyaluran Pembiayaan Bank Syariah } \\
\text { (Dalam Milyar Rupiah) }\end{array}$ \\
\hline $\begin{array}{c}\text { Produk } \\
\text { Pembiayaan }\end{array}$ & $\begin{array}{c}\text { Jumlah } \\
\text { Pembiayaan }\end{array}$ & $\begin{array}{c}\text { Kontribusi } \\
\mathbf{( \% )}\end{array}$ \\
\hline Murabahah & 141.274 & 56,21 \\
Ijarah & 9.017 & 3,59 \\
Mudharabah & 14.316 & 5,69 \\
Musyarakah & 81.709 & 32,51 \\
Qard & 5.026 & 2,00 \\
\hline Total & $\mathbf{2 5 1 . 3 4 2}$ & $\mathbf{1 0 0}$ \\
\hline Sumber: Statistik Perbankan Syariah April 2017 OJK (Data Olahan)
\end{tabular}

Data pada Tabel 1 menunjukkan adanya komposisi dari pembiayaan yang ada di bank syariah bahwa masih didominasi oleh pembiayaan yang non bagi hasil (profit and loss shariang), yaitu sebesar 61, 8 persen, sedangkan pembiayaan dengan akad bagi hasil hanya sebesar 38,2 persen. Secara nominal juga demikian porsi pembiayaan bagi hasil sangat jauh lebih kecil dengan akad non bagi hasil. Jika digabungkan kedua akad bagi hasil mudharabah dan musyarkah hanya sebesar 96.025.000.000 sangat jauh jika dibandingkan dengan satu akad pembiayaan non bagi hasil bank syariah yang mencapai 141.274.000.000. Hal ini menunjukkan bahwa bank syariah yang dikenal sebagai bank bagi hasil kehilangan jati dirinya karena akad dengan bagi hasil tidak menjadi dominan lagi di bank syariah.

Padahal jika kita flashback pada tahun 1997 bank syariah hadir sebagai bank yang menjadi pilihan bagi masyarakat khususnya yang muslim karena konsep berbeda yang ditawarkan. Bahkan awal hadir bank syariah tidak disebut sebagai bank syariah tetapi sebagai bank bagi hasil. Tetapi apakah masih pantas jika saat ini bank syariah sebagai bank bagi hasil jika akad non bagi hasil sudah lebih dominan. Secara syariah akad non bagi hasil tidak dilarang hanya saja bank syariah akan kehilangan jati dirinya akan kehilangan apa yang yang menjadi tujuan mulianya saat pertama kehadirannya. Deputi Komisioner Pengawasan Perbankan Otoritas Jasa Keuangan, Mulya E. Siregar, mengakui pembiayaan bagi hasil di perbankan syariah Indonesia saat ini memang masih rendah, namun sudah ada peningkatan dibanding dengan 10-15 tahun lalu, dimana saat itu porsi pembiayaan bagi hasil hanya sekitar 10 persen. "Tapi sekarang porsi pembiayaan bagi hasil sudah sekitar 39 persen dan yang jual beli menurun dari dulunya 90 persen menjadi 61 persen," kata Mulya. Menurutnya, pergeseran tersebut sudah menunjukkan bahwa perbankan syariah mulai mengembangkan pembiayaan berbasis bagi hasil seperti mudharabah dan musyarakah (Respati 2014).

Dari uraian di atas penulis tertarik untuk bisa melakukan pendalaman tentang mengembalikan jati diri bank syariah sebagai bank dengan konsep bagi hasil bukan sebagai bank konsep jual beli atau lainnya. Konsep bagi hasil menjadi pembeda utama antara bank syariah dengan bank konvensional. Kemudian ketidakpastian pendapatan akan membawa bank syariah justru akan membuka 
peluang tumbuhnya kegiatan ekonomi produktif sehingga memberikan income penghasilan yang lebih besar daripada akad yang bersifat pasti. Adapun yang menjadi tujuan dari penelitian ini yaitu untuk mengetahui perkembangan akad pembiayaan bagi hasil di bank syariah dan untuk mengetahui perlunya dominasi pembiayaan bagi hasil bagi bank syariah.

\section{TELAAH LITERATUR}

Sebelum melakukan penelitian, penulis berusaha menelaah literatur karya ilmiah sebelumnya yang berkaitan dengan judul yang diteliti. Penelitian-penelitian terdahulu yang pernah dilakukan sebelumnya perlu dikemukakan hasilnya sebagai perbandingan penelitian dilakukan penulis.

(Maryati 2014) berpendapat bahwa berdasarkan karakteristik usaha yang ada, pada umumnya nasabah pembiayaan di BPRS mempunyai usaha perdagangan (jual beli), usaha milik pribadi dan tempat usaha juga milik sendiri, serta mayoritas responden menjalankan usaha yang dimilikinya tidak memiliki surat izin usaha secara resmi. Pelaku usaha juga harus berusaha mengelola usaha dengan lebih profesional dan memenuhi aspek legalitas usaha agar memudahkan bagi pihak pemerintah maupun lembaga keuangan untuk melakukan berbagai usaha pemberdayaan dan bantuan permodalan.

(Kara 2013) dalam tulisannya menunjukkan adanya perkembangan produk pembiayaan di bank syariah sebagai upaya peningkatan usaha UMKM di kota Makassar pada masa tahun 2010-2011 yang mengalami pertumbuhan secara fluktuatif. Hal ini menunjukkan bahwa peran serta penyaluran pembiayaan yang dilakukan bank syariah sebagai peningkatan para pelaku usaha mikro kecil dan menengah (UMKM) di kota Makassar belum maksimal. Tingkat rata-rata peningkatan pembiayaan yang disalurkan oleh bank syariah pada periode Januari sampai dengan Desember 2010 mencapai 14,23\%, kemudian pada periode Januari sampai dengan September tahun 2011 sebesar 18,43\%.

(Anisah and Mizan 2012) berpendapat bahwa profit sharing membuat keinginan para investor untuk investasi menunjukkan angka 0,452 termasuk taraf signifikansi sebesar 1 persen. Hasil uji hipotesis menunjukkan bahwa Ha diterima, artinya bahwa antara $\mathrm{x}$ dengan y terdapat pengaruh yang signifikan. Sistem bagi hasil di lembaga keuangan syari'ah memberi mempengaruhi minat para nasabah untuk menanamkan menabung dilembaga keuangan syariah BMT. Dari tahun ketahun, dengan penambahan jumlah nasabah yang terus menerus.

(Amah 2013) berpendapat bahwa dengan prinsip syariah di bank syariah memiliki peran penting untuk menggerakkan roda kegiatan di Indonesia dengan upaya pengembangan dan pemberdayaan sektor UMKM. Bank syariah secara langsung maupun secara tidak langsung, dapat mendukung keberadaan UMKM dalam berkontribusi pertumbuhan ekonomi, memberikan kestabilan ekonomi, membuka penyerapan tenaga kerja lebih luas, hasil pembangunan didistribusikan merata, dunia usaha dikembangkan, serta pendapatan APBN dan APBD dapat ditingkatkan melalui perpajakan. Bank syariah juga berperan dalam menarik minat para investor dari luar negeri ke Indonesia peluang investasi syariah di Indonesia. 


\section{Pembiayaan Bagi Hasil di Bank Syariah}

Usaha bank syariah bentuk penyaluran pembiayaan dengan skema jualbeli menggunakan akad murâbahah, jual beli bay'bi dhamân, jual beli bentuk pesanan (salam), serta skema sewa ijârah, istishnâ', dan akad pembiayaan lainnya. Kemudian juga memiliki produk pembiayaan penyertaan modal dianggap memiliki lebih besar tingkat risiko terutama pembiayaan mudhârabah. Pada pembiayaan mudhârabah, pihak bank syariah akan menyediakan dana 100\% untuk modal usaha, sedang pihak pengusaha memberikan jasa atau bertindak sebagai pengelolaan usaha yang dibiayai. Sebagai pengelolah dana shâhib al-mâl, bank syariah tidak diperkenankan ikut dalam kegiatan yang dilakukan oleh pihak pengelola usaha. Hasil yang diperoleh dari usaha dengan pembiayaan mudharabah harus dibagi hasilkan dua pihak bank syariah dengan pihak pengelola usaha, dibagi dengan porsi disepakati bersama. Begitupun jika terjadi kerugian, maka kerugian modal atau uang seluruhnya atau sebagian ditanggung oleh bank syariah, sedang pihak pengelola dana tidak mendapatkan bayaran apapun. Adanya risiko yang besar (high risk) menyebabkan komposisi penyaluran pembiayaan kepada masyarakat yang lebih banyak menggunakan pembiayaan jual beli (murâbahah), bila dibandingkan bentuk penyertaan modal atau kerjasama (mudhârabah dan musyârakah), padahal memiliki dampak secara langsung bagi pertumbuhan ekonomi seperti tumbuhnya usaha baru (Hadi 2011).

Mudharabah adalah teknik pembiayaan yang pemilik modal menyediakan dana bagi pemakai modal untuk digunakan dalam suatu kegiatan produktif dengan perjanjian bahwa laba yang dihasilkan akan dibagi berdua. Rugi, jika terjadi yang timbul dari proses yang normal, yakni bukan disebabkan kelalaian pengguna dana ditanggung oleh pemilik modal. Pengguna dana tidak menginvestasikan apapun juga selain tenaganya sendiri serta tidak pula mendapatkan upah maupun gaji dari jasanya mengola bisnis. Pemilik modal hanya menyediakan dana saja dan tidak boleh campur tangan dalam manajemen bisnis. Rasio pembagian laba bersifat tetap dan ditentukan diawal kesepakatan, serta diketahui dengan pasti oleh kedua belah pihak. Jika terjadi kerugian, maka pemilik modal kehilangan modalnya sebatas besarnya kerugian itu, sedangkan pengguna dana kehilangan hasil kerjanya. Kesediaan menanggung risiko kerugian itulah yang menjadi pembenar bagi pemilik modal untuk menerima bagian laba. Rasio bagi laba itu disepakati kedua belah pihak serta ditentukan oleh kekuatan pasar (Fahmi 2014).

Para fuqaha telah bersepakat dengan dibolehkannya penggunaan pembiayaan syirkah mudharabah. Adanya kebolehan berdasarkan kesepakatan ulama (ijma') yang bersumber dari Al-qur'an dan Hadist Nabi SAW. Banyak pihak yang membutuhkan akad tersebut tidak semua pihak memiliki dana atau harta, dan tidak semua orang memiliki keahlian dalam berbisnis dan dalam mendayagunakan dan mengelolah hartanya. Sebaliknya juga demikian, tidak semua pihak dapat mengembangkan harta dimiikinya tanpa bantuan pihak lain, meskipun mereka mempunyai banyak modal untuk usaha. Maka dari itu, hal ini menunjukkan perlunya akad kerjasama seperti syirkah mudharabah dapat mewujudkan kemaslahatan dan mafaat bagi semua pihak (Ath-Thayyar et al. 2009). Fatwa DSN Majelis Ulama Indonesia Nomor: 08/DSN-MUI/IV/2000 Tentang penerapan akad mudharabah (Qiradh), telah mengatur produk pembiayaan Mudharabah di bank syariah. 
Pembiayaan musyarakah merupakan produk pembiayaan bank syariah bentuk kemitraan sebagaimana halnya pembiayaan mudharabah. Kedua produk finansial di bank syariah memiliki ciri-ciri dan ketentuan yang berbeda. Musyarakah teknik pembiayaan yang seorang pemilik modal menginvestasikan di dalam bisnis pihak lain. Modal tambahan diberikan kepada pihak lain baik individu maupun kelompok yang sebelumnya telah memiliki dana bagi investasinya. Pihak penyedia dana memberi tambahan modal itu dengan janji, bahwa ia akan mendapatkan bagian laba dari bisnis mereka. Rasio pembagian laba itu bersifat tetap dan telah ditetapkan diawal kesepakatan, serta diketahui oleh kedua belah pihak. Adapun kerugian dibagi menurut porsi bagian modal masingmasing. Rasio laba itu disepakati oleh kedua belah pihak, dan mungkin saja berbeda dengan rasio atau proporsi modal masing-masing yang disertakan di dalam proyek. Hal itu disebabkan kedua belah pihak akan bekerjasama dalam mengelola proyek mereka dalam jumlah yang mereka sepakati bersama (Fahmi 2014). Dewan syariah nasional MUI telah mengeluarkan fatwa tentang pembiayaan musyarakah di lembaga keuangan syariah yaitu fatwa nomor 8/ DSNMUI/IV/2000.

Pembiayaan musyarakah menurut surat edaran otoritas jasa keuangan (SEOJK), nomor 03 tahun 2015, menyebutkan bahwa pembiayaan musyarakah merupakan pembiayaan dengan penyediaan dana atau tagihan untuk kerja sama usaha tertentu yang masing-masing pihak memberikan porsi dana dengan ketentuan bahwa keuntungan akan dibagi sesuai dengan kesepakatan, sedangkan kerugian ditanggung sesuai dengan porsi dana masing-masing.

Adapun menurut Ibn Rusyd bahwa akad syirkah atau musyarakah adalah bentuk akad kerjasama antara dua pihak atau lebih pada usaha tertentu dimana semua pihak menyertakan atau berkontribusi dalam bentuk uang atau dana disepakati bahwa keuntungan yang diperoleh serta risiko yang dapat terjadi akan ditanggung oleh semua pihak porsi sesuai kesepakatan. Akad syirkah telah disepakati dikalangan para fuqaha untuk hukum kebolehannya harus memenuhi rukunnya, adanya ijab dan qabul, demi memperjelaskan bentuk transaksi kegiatan usahanya (Iska 2012).

Dalam penyaluran pembiayaan proyek, bank syariah tidak menerapkan keuntungan yang pasti (fixed return) tidak dapat ditentukan diawal, karena pada hakikatnya sangat memungkinakan munculnya kerugian suatu proyek yang dibiayai, hanyalah Allah semata yang maha mengetahui sedangkan manusia tidak dapat menetukan atau meramalnya. Bank syariah dapat menerapkan sistem penyertaan modal untuk jenis kontrak al-mudharabah dan al-musyarakah menggunakan sistem bagi hasil (profit and loss sharing) berdasarkan pada besarnya keuntungan. Sedangkan untuk pembiayaan jenis jual beli murabahah keuntungan ditetapkan diawal kontrak. Jual beli melalui kredit pemilikan barang/ aktiva (al-murabahah dan al-bai'u bitsaman ajil) sewa (ijarah) karena kemungkinan rugi amat kecil (Aksin 2013).

Penggunanaan sistem bagi profit and loss sharing harga modal dapat ditentukan secara bersamaan dengan peran kegiatan kewirausahaan. Price of capital dan entreprenurship adalah kesatuan integratif yang secara bersamaan dapat diperhitungkan dalam menetukan harga kegiatan produksi. Pandangan syariah uang hanya dapat dikembangkan melalui suatu produktifitas nyata/riil. Tidak boleh adanya tambahan atas pokok uang yang tidak menghasilkan 
produktifitas kegiatan ekonomi. Bentuk perjanjian bagi hasil disepakati adalah proporsi pembagian hasil yang diperoleh dalam bentuk nisbah bagi hasil, ukuran persentase atas kemungkinan hasil produktifitas nyata yang telah diperoleh usaha. Nilai besaran nominal bagi hasil yang diperoleh hanya dapat diketahui setelah hasil pemanfaaatan dana benar-benar telah ada keuntungan jelas diperoleh (Yahya and Agunggunanto 2011).

Kerangka berfikir dalam penelitian ini, yaitu menguraikan fenomena yang ada dilapangan, yang kemudian menunjukkan dengan ketentuan yang seharusnya terkait bank syariah sebagai bank bagi hasil, namun pembiayaannya tidak didominasi oleh pembiayaan bagi hasil, namun didominasi oleh pembiayaan non bagi hasil. Setelah itu diuraikan penelitian yang relevan terkait bagi hasil di bank syariah, dan konsep bagi hasil yang diterapkan, kemudian diperkuat dengan uraian teori yang berkaitan dengan pembiayaan di bank syariah. Serta menemukan dari hasil penelitian dan melakukan analisis atas penelitian tersebut.

\section{METODE PENELITIAN}

Metode dalam penelitian ini adalah kualitatif yang difokuskan pada produk pembiayaan dengan akad bagi hasil yang dimiliki bank syariah. Jenis data yang digunakan dalam tulisan ini yaitu data kualitatif yang terdiri data primer dan data sekunder antara lain berasal dari teori-teori dari berbagai literatur dan data-data dari hasil yang telah tersaji dari suatu lembaga. Teknik pengumpulan data yang digunakan dalam tulisan ini adalah studi pustaka dan pengamatan. Teknis analisis data yang digunakan adalah dengan menggunakan pendekatan kualitatif deskriptif yaitu dengan cara memaparkan metode teori produk pembiayaan dengan akad bagi hasil. Serta kondisi dan perkembangan pembiayaan dengan akad bagi hasil yang ada di bank syariah.

\section{HASIL DAN PEMBAHASAN PENELITIAN}

\section{Perkembangan Pembiayaan Bagi Hasil di Bank Syariah}

Tabel 2. Pertumbuhan Pembiayaan di Bank Syariah (Dalam Milyar Rupiah)

\begin{tabular}{cccc}
\hline \multirow{2}{*}{ Jenis Pembiayaan } & $\begin{array}{c}\text { Desember } \\
\mathbf{2 0 1 9}\end{array}$ & $\begin{array}{c}\text { Desember } \\
\mathbf{2 0 2 0}\end{array}$ & $\begin{array}{c}\text { Pertumbuhan } \\
(\mathbf{\%})\end{array}$ \\
\hline Mudharabah & 13.779 & 11.854 & $-13,97$ \\
Musyarakah & 157.491 & 174.919 & 11,07 \\
Murabahah & 160.654 & 174.301 & 8,49 \\
Ijarah & 10.589 & 8.635 & $-18,45$ \\
Qard & 10.572 & 11.872 & 12,29 \\
\hline Total & $\mathbf{3 5 3 . 0 8 5}$ & $\mathbf{3 8 1 . 5 8 1}$ & $\mathbf{8 , 0 7}$ \\
\hline
\end{tabular}

Sumber: Statistik Perbankan Syariah (Data Olahan)

Data pada Tabel 2 menunjukkan adanya perkembangan pembiayaan di bank syariah pada periode Desember 2019 sampai dengan Desember 2020. Data menunjukkan perkembangan terbesar terjadi pada akad Qard yaitu tumbuh sebesar 12,29 persen. Sedangkan pertumbuhan kedua dialami oleh akad 
musyarakah yaitu sebesar 11,07 persen. Kemudian ada dua produk pembiayaan yang mengalami penurunan yaitu produk mudharabah turun sebesar -13,97 persen dan produk ijarah turun sebesar $-18,45$ persen. Ada dua pembiayaan yang menggunakan akad prinsip bagi hasil yaitu mudharabah dan musyarakah. Akad lainnya pembiayaan non bagi hasil. Meskipun jika dilihat pertumbuhan akad musyarakah mengalahkan pertumbuhan murabahah yang hanya tumbuh 8,49 persen, hanya saja secara nominal jika digabungkan kedua akad bagi hasil musyarakah dan mudharabah masih sangat kecil jika dibandingkan dengan satu akad non bagi hasil baik pada periode Desember 2019 maupun Desember 2020. Pada periode Desember 2020 pembiayaan dengan skema bagi hasil mencapai 186.773.000.000.000 rupiah, pembiayaan non bagi hasil mencapai 194.808.000.000.000 rupiah. Hal ini menunjukkan bahwa porsi pembiayaan di bank syariah masih didominasi oleh pembiayaan non bagi hasil.

\section{Perlunya Dominasi Pembiayaan Akad Bagi Hasil (Profit and Loss Sharing)}

Alasan didirikannya bank syariah diantaranya karena keadilan yang terdapat pada bank syariah. Di kalangan investor barat terjadi pergeseran paradigma dalam berinvestasi yaitu mereka tidak lagi berinvestasi karena alasan tertarik dengan bunga yang kelihatannya saja menjanjikan keuntungan berlipat ganda seketika. Namun kini mereka lebih kritis penghasilan yang mungkin diperoleh melalui metode institusi pemutaran uang, sehingga sistem bagi hasil yang diterapkan oleh bank syariah lebih logis dan fair bagi mereka. Dengan adanya bank syariah maka semua umat terutama umat Islam terhindar dari riba dalam kegiatan muamalahnya memperoleh kesejahteraan lahir batin dan sesuai dengan perintah agamanya.

Bank syariah merupakan salah satu bank yang menerapkan keadilan, kemitraan, transparan dan juga sistem yang jauh dari riba karena bank syariah tidak menerapkan sistem penetapan bunga melainkan menggunakan sistem bagi hasil bank syariah. Penetapan bunga dianggap haram oleh bank syariah karena termasuk dalam riba yang mana diharamkan oleh ajaran islam oleh karena itu sistem bunga diganti menjadi nisbah bagi hasil. Selain itu sistem tersebut menjadi salah satu ciri khas dari bank syariah sehingga diminati oleh banyak orang. Hal tersebut karena nantinya bagi hasil tersebut disesuaikan dengan kesepakatan yang dilakukan oleh kedua belah pihak sehingga akan sangat adil. Selain itu juga nantinya jika mengalami kerugian maka kerugian tersebut akan ditanggung oleh kedua belah pihak tidak seperti bunga yang mana jika mengalami kerugian yang menanggung adalah peminjamnya saja.

Antara bank konvensional dan bank syariah memang memberikan beberapa perbedaan contohnya saja seperti jika pada sistem penetapan bunga nantinya jika mengalami kerugian maka yang menanggung hanyalah pihak peminjam saja, pembayaran bunga tetap, eksistensi bunga diragukan oleh beberapa agama, investasi yang bisa dibilang haram karena mengandung riba dan juga tidak terdapat dewan syariah. Sedangkan untuk sistem bagi hasil bank syariah sendiri adalah jika mengalami kerugian maka akan ditanggung oleh kedua belah pihak, menggunakan sesuai dengan kesepakatan dan lebih adil, tidak ada yang meragukan hukum dari bagi hasil tersebut, melaksanakan investasi yang halal saja, penyaluran dana melalui dewan pengawas syariah. Oleh karena itu 
sistem nisbah bagi hasil lebih diminati oleh sebagian besar orang (Kompasiana 2014).

Ada tiga alasan penting perlunya dominasi pembiayaan bagi hasil di bank syariah, yaitu: Pertama, bank syariah sejak pertama kemunculannya sudah melekat sebagai bank bagi hasil sehingga punya spirit serta tujuan yang jelas yaitu mengedepankan konsep bagi hasil. Hal ini harus dikembalikan bank syariah harus lebih banyak menggunakan pembiayaan dengan akad bagi hasil. Kedua, bank syariah harus memiliki karakter yang bisa ditonjolkan yang membedakannya dengan bank konvensional. Akad pembiayaan bagi hasil menjadi pembeda utama yang dimiliki oleh bank syariah. Bank konvensional segalanya telah pasti, bahkan bisa menyalahai sunnatullah kehidupan, sedangkan konsep bagi hasil lebih adil bagi semua pihak. Konsep bagi hasil tidak akan ditemukan pada produk bank konvensional. Makin banyak bank syariah menggunakan produk pembiayaan bagi hasil, maka akan nampak perbedaan yang dapat dirasakan antara bank syariah dengan bank konvensional. Ketiga, bank syariah harus banyak memberikan pembiayaan dengan akad bagi hasil (profit and loss sharing) karena akan membuka peluang untuk mendapatkan profit yang lebih besar pula. Risiko besar yang dapat dihadapi juga menjanjikan keuntungan yang besar pula. Tinggal tugas bank syariah menyiapkan segala sesuatunya agar pembiayaan bagi hasil dapat secara optimal. Jadi pembiayaan dengan bagi hasil bisa membuka peluang adanya keuntungan yang besar berbeda dengan pembiayaan non bagi hasil yang keuntungannya bersifat tetap.

\section{KESIMPULAN}

Perkembangan pembiayaan bagi hasil di bank syariah pada periode Desember 2019 sampai Desember 2020 cukup baik terlihat pertumbuhan pembiayaan musyarakah mencapai 11,07 persen. Pertumbuhan terbesar kedua setelah akad pembiayaan qard yaitu sebesar 12,29 persen. Hanya saja yang cukup jauh tertinggal akad pembiayaan mudharabah yang mengalami penurunan sebesar $-13,97$ persen. Meskipun akad pembiayaan bagi hasil di bank syariah tumbuh tapi dari sisi besaran porsi pembiayaan secara nominal jauh tertinggal dengan akad pembiayaan non bagi hasil yang mencapai 198.808.000.000.000 rupiah. Bank syariah perlu melakukan perombakan produk pembiayaan. Dominasi pembiayaan akad bagi hasil di bank syariah perlu dilakukan untuk mengembalikan jati diri dan spirit awal bank syariah sebagai bank bagi hasil. Dominasi pembiayaan bagi hasil di bank syariah akan menjadi pembeda utama antara bank syariah dengan bank konvensional. Serta dominasi pembiayaan akad bagi hasil di bank syariah akan membuka peluang bank syariah untuk memperolah keuntungan yang lebih besar jika dibandingkan dengan pembiayaan non bagi hasil.

Penelitian ini bermanfaat di bidang akademik sebagai khasanah keilmuan tentang konsep dasar bagi hasil di bank syariah dan memaksimalkan pembiayaan bagi hasil di bank syariah. Secara praktis akan menunjukkan kekuatan dari bagi hasil sebagai pembiayaan yang dapat diterapkan dengan baik, dan dapat menjadi pembeda dengan bank konvensional. Manfaat secara umum menjadi edukasi untuk meningkatkan pemahaman masyarakat tentang produk-produk bank syariah khususnya produk bagi hasil. 
Bank syariah harus banyak melakukan modifikasi setiap produk yang dimilikinya. Modifikasi dilakukan bukan dalam rangka untuk keluar dari apa yang telah dicita-citakan bank syariah sejak awal kemunculannya. Bank syariah sudah harus mengubah porsi bagi hasil lebih banyak menggunakan akad pembiayaan dengan skema bagi hasil (profit and loss sharing), sebagaimana telah melekat bank syariah sebagai bank bagi hasil. Diharapkan kepada semua pihak untuk mendorong pertumbuhan bank syariah agar bisa mendukung laju perekonomian di suatu negara. Perlu ada regulasi yang bisa mengatur agar bank syariah hendak memberikan porsi yang banyak bagi pembiayaan dengan akad bagi hasil. Produk pembiayaan harus menjadi dominan dan banyak, sedangkan akad non bagi hasil hanya sebagai pelengkap dari produk yang dimiliki oleh bank syariah.

\section{DAFTAR PUSTAKA}

Agza, Yunita, and Darwanto Darwanto. 2017. "Pengaruh Pembiayaan Murabahah, Musyarakah, Dan Biaya Transaksi Terhadap Profitabilitas Bank Pembiayaan Rakyat Syariah.” IQTISHADIA: Jurnal Kajian Ekonomi Dan Bisnis Islam $10 \quad$ (1): 225-45. https://journal.iainkudus.ac.id/index.php/IQTISHADIA/article/view/2550.

Aksin, Nur. 2013. "Perbandingan Sistem Bagi Hasil Dan Bunga Di Bank Muamalat Indonesia Dan CIMB Niaga." JEJAK: Jurnal Ekonomi Dan Kebijakan $6 \quad$ (2): 112-25. https://journal.unnes.ac.id/nju/index.php/jejak/article/view/3882.

Amah, Nik. 2013. "Bank Syariah Dan Umkm Dalam Menggerakkan Roda Perekonomian Indonesia: Suatu Kajian Literatur." Assets: Jurnal Akuntansi Dan Pendidikan 2 (1): 48-54. https://doi.org/10.25273/jap.v2i1.561.

Anisah, Yuli, and Mizan Mizan. 2012. "Pengaruh Sistem Profit Sharing Terhadap Keinginan Nasabah Untuk Berinvestasi Pada Baitul Maal Tamwil (BMT) Di Kota Banda Aceh.” Jurnal Ekonomi Dan Bisnis 12 (1): 1-6.

Ath-Thayyar, Abdullah Muhammad, Abul-Hasan, Taqdir Arsyad, Abdullah bin Muhammad Al-Muthlaq, Muhammad bin Ibrahim, and Miftahul Khairi. 2009. Ensiklopedi Fiqh Muamalah Dalam Pandangan 4 Madzhab (Terjemahan). Yogyakarta: Maktabah Al-Hanif.

Bank Indonesia. 2013. Outlook Perbankan Syariah Tahun 2013. Bank Indonesia. Jakarta: Bank Indonesia.

Darsono, Darsono, Ali Sakti, Enny Suryanti, Siti Astiyah, and Androecia Darwis. 2017. Masa Depan Keuangan Syariah Di Indonesia. Bogor: Tazkia Publishing.

Fahmi, Irham. 2014. Bank Dan Lembaga Keuangan Lainnya Teori Dan Aplikasi. Bandung: Alfabeta.

Hadi, Ahmad Chairul. 2011. "Problematika Pembiayaan Mudharabah Di Perbankan Syariah Indonesia." Al-Iqtishad: Jurnal Ilmu Ekonomi Syariah 3 193-208. http://www.journal.uinjkt.ac.id/index.php/iqtishad/article/view/2521.

Ikatan Bankir Indonesia. 2014. Mengelola Bisnis Pembiayaan Bank Syariah. Jakarta: Gramedia Pustaka Utama. 
Iska, Syukri. 2012. Sistem Perbankan Syariah Di Indonesia Dalam Perspektif Fikih Ekonomi. Yogyakarta: Fajar Media Press.

Kara, Muslimin. 2013. "Konstribusi Pembiayaan Perbankan Syariah Terhadap Pengembangan Usaha Mikro Kecil Dan Menengah (UMKM) Di Kota Makassar." Asy-Syir'ah: Jurnal Ilmu Syari'ah Dan Hukum 47 (1). http://asy-syirah.uin-suka.com/index.php/AS/article/view/64.

Kompasiana. 2014. "Alasan Sebagian Besar Orang Memilih Sistem Bagi Hasil Bank Syariah.” Kompasiana.com. https://www.kompasiana.com/monic/54f99cf4a33311d7588b4a40/alasansebagian-besar-orang-memilih-sistem-bagi-hasil-bank-syariah.

Maryati, Sri. 2014. "Peran Bank Pembiayaan Rakyat Syariah Dalam Pengembangan Umkm Dan Agribisnis Pedesaan Di Sumatera Barat." Economica: Jurnal Program Studi Pendidikan Ekonomi 3 (1): 1-17. https://doi.org/10.22202/economica.2014.v3.i1.231.

Metrotvnews. 2016. "Economic Challenges: Hijrah Ke Bank Syariah.” Jakarta: MetroTV. https://www.youtube.com/watch?v=wF0oZzblJkQ.

Muhammad, Muhammad. 2012. Teknik Perhitungan Bagi Hasil Di Bank Syariah. Yogyakarta: UII Press.

Respati, Yogie. 2014. "Pembiayaan Bagi Hasil Bank Syariah Mulai Meningkat." http://mysharing.co/pembiayaan-bagi-hasil-bank-syariah-mulaimeningkat/.

Trimulato, Trimulato. 2017. "Pola Bisnis Rasulullah Spirit Bagi Perkembangan Bank." Syari'ah: Jurnal Ekonomi Syari'ah 5 (1): 1-32. http://ejournal.fiaiunisi.ac.id/index.php/syariah/article/view/136.

Yahya, Muchlis, and Edy Yusuf Agunggunanto. 2011. "Teori Bagi Hasil (Profit And Loss Sharing) Dan Perbankan Syariah Dalam Ekonomi Syariah." Jurnal Dinamika Ekonomi Pembangunan 1 (1): 65-73. https://doi.org/10.14710/jdep.1.1.65-73. 